\title{
(C) OPEN ACCESS \\ New headaches with normal inflammatory markers: an early atypical presentation of giant cell arteritis
}

\author{
Ruchir Singh, ${ }^{1,2} \|$ fita Sahbudin, ${ }^{1,2}$ Andrew Filer ${ }^{1,2}$
}

'Rheumatology Research Group, Institute of Inflammation and Ageing, University of Birmingham, Birmingham, UK ${ }^{2}$ Rheumatology Department, University Hospitals Birmingham NHS Foundation Trust, Birmingham, UK

Correspondence to

Dr Ilfita Sahbudin, i.sahbudin@bham.ac.uk

Accepted 18 May 2018

Check for updates

(c) BMJ Publishing Group Limited . Re-use permitted under CC BY-NC. No commercial re-use. See rights and permissions. Published by BMJ.

To cite: Singh R, Sahbudin I, Filer A. BMJ Case Rep Published Online First: [please include Day Month Year]. doi:10.1136/bcr-2017223240

\section{SUMMARY}

An 80-year-old man presented repeatedly to his general practitioner with 3 months of unexplained persistent frontal headaches. CT head revealed no diagnosis. His dentist diagnosed his co-existing jaw pain as bruxism. Three months later, the patient happened to attend a routine ophthalmology follow-up appointment. During this routine appointment, features of giant cell arteritis (GCA) including worrying visual complications were first noted. His inflammatory markers (C-reactive protein and erythrocyte sedimentation rate) were not significantly raised-contrary to the norm. A temporal artery ultrasound and biopsy were performed, in light of the history. This confirmed GCA. He was commenced on high-dose oral prednisolone and was managed by ophthalmology and rheumatology. At 4 weeks, symptoms resolved with no permanent visual loss despite a prolonged initial symptomatic period. Multiple symptomatic presentations to different specialties should therefore alert clinicians to a unifying diagnosis, for example, vasculitis. Serious illnesses may present with severe symptoms despite normal screening investigations.

\section{BACKGROUND}

This case provides a warning on how easily common presentations may be dismissed, and serious diagnoses delayed if a broad list of differentials including additional systemic involvement is not considered.

This case illustrates how unexplained persistent headaches should raise the index of suspicion of atypical causes such as vasculitis. A judgement on the likelihood of vasculitis can be made at the time of clinical review with focused questions. This patient visited three different health professionals before a correct diagnosis was reached. Piecing together different symptoms and a patient timeline could have led to an earlier diagnosis. Asking 'red flag' questions is paramount in ensuring serious conditions are not missed. This is particularly important in systemic diseases, as patients are not necessarily aware of which symptoms are relevant. Thus, they may not volunteer the relevant clinical information unless prompted. This last point enabled the ophthalmologist to consider giant cell arteritis (GCA) as a diagnosis.

We demonstrate that although investigation results may be characteristic, they cannot always be relied on to exclude systemic diseases. In this case, inflammatory markers were not significantly raised, an unusual but well-documented occurrence. This is supported by a study that identified 167 patients fulfilling the American College of Rheumatology criteria for GCA over a 48-year period. Of these patients, nine had a reported erythrocyte sedimentation rate (ESR) of less than $40 \mathrm{~mm} /$ hour. Six of the nine patients had an ESR of $<30 \mathrm{~mm} /$ hour. All nine of these patients had a positive temporal artery biopsy. ${ }^{1}$ History taking and clinical judgement should therefore always take precedence in forming a diagnosis, and diagnoses not to be ruled out on the basis of normal tests; an important message in today's investigation-driven medical practice.

In the case of GCA, important screening questions to consider should include: scalp tenderness, temporal headaches, jaw claudication, visual disturbances, polymyalgia and constitutional symptoms.

\section{CASE PRESENTATION}

An 80-year-old man with a medical history of glaucoma, hypertension and first degree heart block presented with a 3-month history of frontal headaches. A routine CT head was requested by his general practitioner (GP). This showed no intracranial masses or bony lesions but incidentally revealed a mature lacunar infarct of the left ventral thalamus. There was no radiographic cause determined for his headaches.

Alongside his headaches, the patient developed bilateral jaw pain with claudication. $\mathrm{He}$ independently sought advice from his dentist and returned with a diagnosis of bruxism.

Three days after the CT scan (3 months after initial presentation to healthcare), the patient visited ophthalmology for a routine glaucoma follow-up appointment. The ophthalmologist elicited episodes of diplopia, amaurosis fugax and significant weight loss in the preceding months. There was no history of scalp tenderness, fever or proximal muscle pain and stiffness. Examination revealed bilateral tender, nodular and weakly pulsatile temporal arteries. There was no relative afferent pupillary defect or anterior ischaemic optic neuropathy.

In light of the ongoing headaches, jaw claudication, diplopia, amaurosis fugax and weight loss, a diagnosis of GCA was suspected. The patient was referred the same day to the rheumatology department for prompt review.

\section{INVESTIGATIONS}

Inflammatory markers were not significantly raised: C-reactive protein (CRP) $11 \mathrm{mg} / \mathrm{L}(<10)$ 


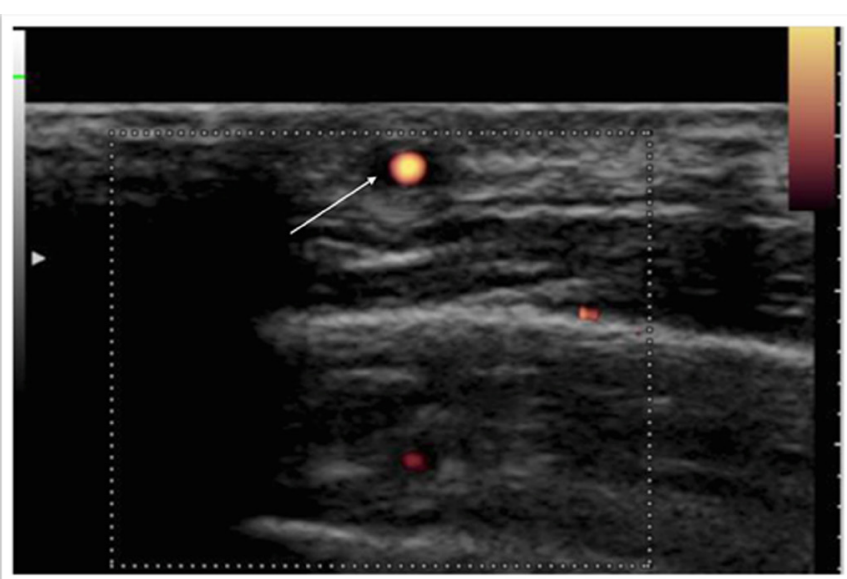

Figure 1 Craniofacial soft tissue ultrasound. Halo sign of right temporal artery indicative of giant cell arteritis. Arrow indicates vessel wall.

and ESR $15 \mathrm{~mm} /$ hour (1-19). Recognising that normal inflammatory markers do not rule out GCA, rheumatologists arranged urgent investigation. Temporal and axillary artery ultrasound (US) demonstrated a characteristic positive halo sign in the right temporal artery (figure 1). A right temporal artery biopsy (TAB) revealed a muscular artery with focal adventitial chronic inflammation and intimal hyperplasia with mild inflammation (figure 2), consistent with GCA.

\section{DIFFERENTIAL DIAGNOSIS}

Key differentials ${ }^{2}$ :

'Primary' headaches

- Migraine.

- Tension type.

- Cluster.

'Dangerous' headaches

- Intracranial haemorrhage.

- Masses (benign or malignant).

- Metastases.

Referred pain

- Temporomandibular joint dysfunction.

- Dental abscess.

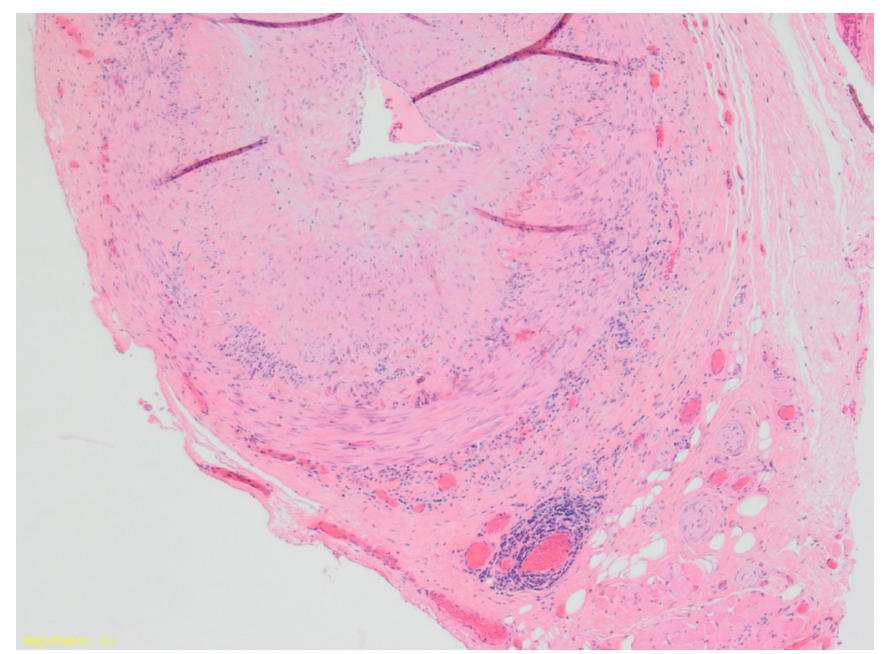

Figure 2 Right temporal artery biopsy. Mild lymphocytic infiltrate in media and around vasa vasora and intimal thickening of right temporal artery.
- Cervical spondylosis.

- Otalgia.

- Trigeminal neuralgia.

Vision related

- Transient ischaemic attack.

- Glaucoma.

\section{TREATMENT}

Steroid treatment should be commenced immediately once a diagnosis of GCA is suspected, while awaiting further investigations. Sixty milligrams of prednisolone was initiated due to the presence of jaw claudication and visual symptoms in accordance with the British Society of Rheumatology guidelines. ${ }^{3} \mathrm{He}$ was co-prescribed lansoprazole and alendronate for gastroprotection/bone protection and counselled regarding long-term steroid management and safety.

\section{OUTCOME AND FOLLOW-UP}

At 4-week follow-up, his symptoms improved significantly and inflammatory markers remained low (CRP $<3$, ESR 2). Oral prednisolone was tapered down gradually with frequent review of intraocular pressures to exclude glucocorticoid-induced exacerbation of glaucoma. Subsequent follow-ups confirmed inactive GCA disease, with no episodes of relapse.

\section{DISCUSSION}

GCA was first described histologically by Bayard Horton. ${ }^{4}$ It is the most common of all vasculitides with a predilection for medium to large vessels in patients aged $>50$ years. The estimated incidence of GCA is 1 per 10000 person-years based on specific selection criteria. ${ }^{5}$ Inflammation of vessel walls causes reduced patency of the vessel lumen resulting in end tissue ischaemia and subsequent symptoms. ${ }^{6}$

Headaches are a common symptom and may have many plausible causes. A prospective study examined 262 patients, aged $\geq 65$ years with headache from primary care, neurology clinics and hospital inpatient referrals. From this, 362 headache episodes were coded and outcomes classified against the International Classification of Headaches Disorders second Edition. Primary headaches accounted for $62.2 \%$ of cases, most often tension type and migraine. GCA was responsible for only two headache cases. ${ }^{8}$

Although the overall incidence of GCA in patients presenting with headaches is very low, clinicians should consider it as an important differential in those where the presentation is atypical and not responding to conventional investigation or treatment. The diagnosis of suspected GCA is largely clinical. However, as with other vasculitides, multiorgan symptoms may prompt multiple presentations to GPs and other specialities including dentists, ophthalmologists, ENT and stroke services. Pattern recognition of key signs and symptoms is therefore vital for prompt investigation and treatment.

Key factors that have a high likelihood ratio (LR) of biopsy proven GCA include: the presence of jaw claudication (LR 4.2), diplopia (LR 3.4) and temporal artery beading, prominence or tenderness (LR 4.6, 4.3, 2.6, respectively). ${ }^{9}$ Thus, these should be sought for in clinical history and examination among other classical features, for example, aged $\geq 50$ years, scalp tenderness, systemic symptoms and polymyalgia. ${ }^{3}$

Jaw claudication predicts the likelihood of developing permanent visual loss. ${ }^{9} 10$ The combination of headache and jaw pain should always raise suspicion of GCA. Reassuringly, the incidence of visual symptoms and complications in patients with 
GCA has reduced in the last 50 years, and this may be in part due to greater clinician awareness, improved diagnostic methods and recognition of the need for prompt treatment. ${ }^{11}$

Classically, ESR is a diagnostic indicator for GCA and a normal ESR reduces the likelihood of biopsy positive GCA. ${ }^{9}$ However, as in this case, elevated inflammatory markers may not always be present. Other cases report similar findings, with one case of a 73 year old with GCA, in whom ESR was only mildly elevated at $27 \mathrm{~mm} /$ hour. $^{12}$ Similarly, a 74 year old with right-sided temporal headaches and initially normal inflammatory markers (CRP $<5 \mathrm{mg} / \mathrm{L}$ ), re-presented 6 months later with scalp tenderness, jaw claudication and biopsy proven GCA. ${ }^{13}$ Another elderly woman who presented with headaches, visual symptoms and jaw claudication was found to have normal ESR and CRP on repeated occasions. Despite this, US and biopsy assessment revealed GCA. ${ }^{14}$ Rana et al also reported a case of delayed diagnosis of GCA. An 81-year-old woman was presented with chronic headaches and an unremarkable CT head. Subsequently, she also presented to ophthalmology with a history of jaw claudication and irreversible visual symptoms. ${ }^{15}$

In our case, despite normal inflammatory markers, both TAB and temporal artery US were positive. The use of temporal artery US as an alternative to TAB has been examined in a large prospective multicentre study. This study $(\mathrm{n}=381)$ showed that the sensitivity for $\mathrm{TAB}$ was $39 \%$ with $100 \%$ specificity where clinical diagnosis was the reference standard. In comparison, temporal artery US had a sensitivity of $54 \%$ but a lower specificity of $81 \%$. In addition, performing TAB on only those with negative temporal artery US would increase the sensitivity to $65 \%$ with $81 \%$ specificity. This would potentially reduce the need for TAB by $43 \% .{ }^{16}$ Our case highlights the need for referral to secondary care for investigations as above, in order to elicit positive findings in those with atypical features.

Learning points

- Delayed diagnosis and treatment of giant cell arteritis (GCA) may lead to permanent visual loss.

- Suspect underlying systemic diseases, for example, vasculitis in patients presenting with persistently unexplained symptoms or multiple presentations.

- Confirm the presence (or absence) of red flags such as jaw claudication, visual disturbance and scalp tenderness in patients with headaches, to avoid missed opportunities in timely diagnosis.

- Normal or low-normal inflammatory markers do not exclude GCA; specialist review is required if red flag symptoms are present.
In summary, we present an unusual, but important case of delayed GCA diagnosis. The normal inflammatory markers at initial presentation led to a lower index of suspicion that GCA was a possible differential diagnosis. We suggest not dismissing GCA as a differential based on normal inflammatory markers, but to explore atypical presentations and in particular seek the presence of key symptoms. Education regarding clinical presentations and advancements in imaging can help improve the recognition of atypical GCA presentations such as in this case.

Contributors RS drafted the manuscript. IS and AF reviewed and edited the manuscript.

Funding The authors have not declared a specific grant for this research from any funding agency in the public, commercial or not-for-profit sectors.

Competing interests None declared.

Patient consent Obtained.

Provenance and peer review Not commissioned; externally peer reviewed.

Open access This is an open access article distributed in accordance with the Creative Commons Attribution Non Commercial (CC BY-NC 4.0) license, which permits others to distribute, remix, adapt, build upon this work non-commercially, and license their derivative works on different terms, provided the original work is properly cited, appropriate credit is given, any changes made indicated, and the use is non-commercial. See: http://creativecommons.org/licenses/by-nc/4.0/.

\section{REFERENCES}

1 Salvarani C, Hunder GG. Giant cell arteritis with low erythrocyte sedimentation rate: frequency of occurence in a population-based study. Arthritis Rheum 2001:45:140-5.

2 Hainer BL, Matheson EM. Approach to acute headache in adults. Am Fam Physician 2013:87:682-7.

3 Dasgupta B, Borg FA, Hassan N, et al. BSR and BHPR guidelines for the management of giant cell arteritis. Rheumatology 2010;49:1594-7.

4 Roberts WC, Zafar S, Ko JM. Morphological features of temporal arteritis. Proc 2013;26:109-15.

5 Petri H, Nevitt A, Sarsour K, et al. Incidence of giant cell arteritis and characteristics of patients: data-driven analysis of comorbidities. Arthritis Care Res 2015;67:390-5.

6 Weyand $\mathrm{CM}$, Goronzy JJ. Clinical practice. Giant-cell arteritis and polymyalgia rheumatica. N Engl J Med 2014;371:50-7.

7 Headache Classification Subcommittee of the International Headache Society. The international classification of headache disorders: 2nd edition. Cephalalgia 2004;24(Suppl 1):9-160.

8 Ruiz M, Pedraza MI, de la Cruz C, et al. Headache in the elderly: characteristics in a series of 262 patients. Neurologia 2014;29:321-6.

9 Smetana GW, Shmerling RH. Does this patient have temporal arteritis? JAMA 2002;287:92-101.

10 Liozon E, Dalmay F, Lalloue F, et al. Risk factors for permanent visual loss in biopsyproven giant cell arteritis: a study of 339 patients. J Rheumatol 2016;43:1393-9.

11 Singh AG, Kermani TA, Crowson CS, et al. Visual manifestations in giant cell arteritis: trend over 5 decades in a population-based cohort. J Rheumatol 2015;42:309-15.

12 Cheema MR, Ismaeel SM. Temporal arteritis with erythrocyte sedimentation rate $<50$ $\mathrm{mm} / \mathrm{h}$ : a clinical reminder. Clin Interv Aging 2016;11:185-8.

13 Yu-Wai-Man P, Dayan MR. Giant cell arteritis with normal inflammatory markers. Acta Ophthalmol Scand 2007;85:460.

14 Yoeruek E, Szurman P, Tatar O, et al. Anterior ischemic optic neuropathy due to giant cell arteritis with normal inflammatory markers. Graefes Arch Clin Exp Ophthalmol 2008;246:913-5.

15 Rana AQ, Saeed U, Khan OA, et al. Giant cell arteritis or tension-type headache?: a differential diagnostic dilemma. J Neurosci Rural Pract 2014;5:409-11.

16 Luqmani R, Lee E, Singh S, et al. The role of ultrasound compared to biopsy of Temporal Arteries in the Diagnosis and Treatment of Giant Cell Arteritis (TABUL): a diagnostic accuracy and cost-effectiveness study. Health Technol Assess 2016;20:1-238. 
Copyright 2018 BMJ Publishing Group. All rights reserved. For permission to reuse any of this content visit http://group.bmj.com/group/rights-licensing/permissions.

BMJ Case Report Fellows may re-use this article for personal use and teaching without any further permission.

Become a Fellow of BMJ Case Reports today and you can:

- Submit as many cases as you like

- Enjoy fast sympathetic peer review and rapid publication of accepted articles

- Access all the published articles

- Re-use any of the published material for personal use and teaching without further permission

For information on Institutional Fellowships contact consortiasales@bmjgroup.com

Visit casereports.bmj.com for more articles like this and to become a Fellow 